\title{
Media Digitalization, an Analysis of Financial Distress In a Newspaper Company-Evidence from Indonesia
}

\author{
Hastuti $^{1}$, Kamalah Saadah ${ }^{2}$, Lifia Meilani ${ }^{3}$ \\ \{hastuti@polban.ac.id ${ }^{1}$, kamalah.mala@gmail.com ${ }^{2}$, meilanilifia@gmail.com ${ }^{3}$ \} \\ Department of Accounting, Bandung State Polytechnic, Ciwaruga, Bandung, Indonesia ${ }^{1,3}$ \\ Department of Accounting, University of Swadaya Gunung Jati, Cirebon, Indonesia ${ }^{2}$
}

\begin{abstract}
The media digitalization during the industrial revolution 4.0 poses threats for print media companies. The fall of various print media in the US gives a signal that print media companies in many countries need to be aware of the risk of bankruptcy. Identification of financial distress is necessary to improve their financial condition. This study aimed to obtain empirical evidence about the factors that influence financial distress in one of the leading newspaper companies in Indonesia. The data analysis technique used was multiple linear regression analysis using SPSS. The findings of this study showed that independent variables had influences on financial distress partially and simultaneously, except the sales growth ratio where the sales growth was improved when the company was in low financial distress. Meanwhile, the total debt to asset ratio and profit margin on sales had an opposite influence on most of the previous studies.
\end{abstract}

Keywords: Current Ratio, Total Debt to Asset Ratio, Return on Asset, Profit Margin on Sales, Sales Growth Ratio, Financial Distress.

\section{Introduction}

The industrial revolution 4.0 leads to changes in all aspects of life. One of them is in the print media business world. Challenges and threats arise along with the technology development so that the print media needs to adjust for maintaining its existence. The fall of print media companies in the US signaled that print media companies in the world must be aware of liquidation possibility [1]. The following graph illustrates the circulation conditions of newspaper sales in the United States can be seen in Fig.1.

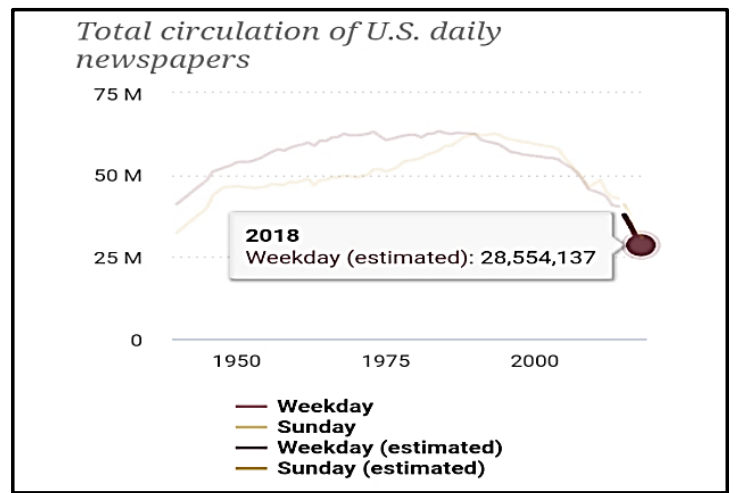

Fig. 1. The estimated circulation of newspaper sales in the United States 
The condition presented in figure 1 is not much different from the situation in Indonesia. Data from the Press Council stated that the increase access to online media and digital social media influences print media. The data showed that the circulation of 1,100 print media in Indonesia at the end of 2013 increased by $0.25 \%$ [2].

The low growth in the circulation caused newspaper companies such as PT. XYZ, a leading newspaper company in Indonesia, experiencing a decline in its net income. The problems arising from the decrease of the net income were (1) PT. XYZ postponed the salary payment to its employees at least once during 2014-2018, (2) PT. XYZ acquired a subsidiary at the end of the 2019 period, and (3) PT. XYZ sold several considerable value fixed assets to meet the company's liabilities. The following graph presents PT. XYZ net profit in 2014-2018 can be seen in Fig.2.

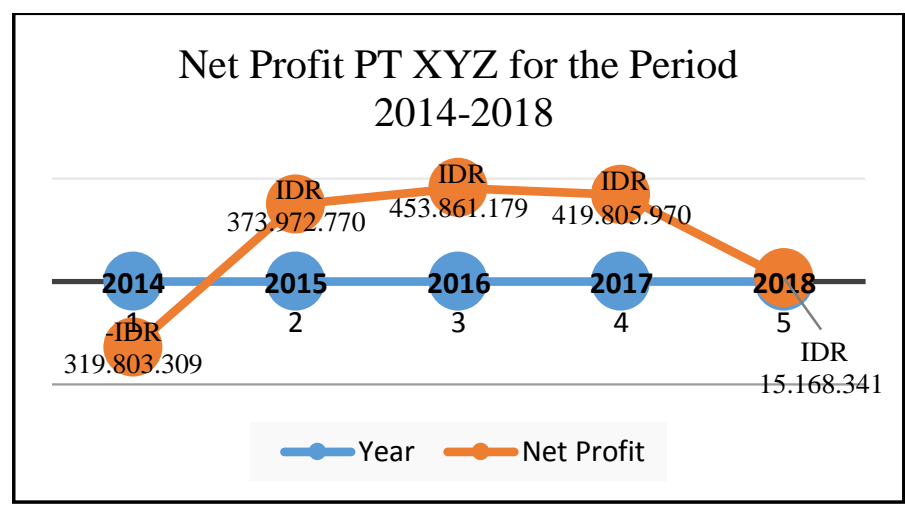

Fig. 2. PT XYZ Net Profit in 2014-2018

Source: PT.XYZ Financial Statements in 2014-2018

Based on these problems, companies must improve their short-term and long-term strategies to anticipate global developments. In this case, if the companies are unable to improve their strategy and performance, they will experience financial difficulties in the future and lead them to bankruptcy. According to [3], financial difficulties occur due to the company's disability to maintain financial performance stability, which causes losses for the period concerned.

According to (Rodoni \& Ali, 2010) in [4], three situations can cause financial distress, namely insufficient capital, amount of debts and interest expenses, and losses. Financial distress is a stage of decline in financial conditions experienced by a company and occurs before the company goes bankrupt or liquidated [5]. Therefore, a company needs to understand and analyze the possibility of financial distress so that it can avoid these conditions.

Indicators for predicting financial distress according to (Foster, 1986) in [6] are (1) cash flow analysis for the present and future periods; (2) company's strategy analysis to consider potential competitors, cost structure, expansion plans in the industry, company's ability to continue rising costs, management quality, and others; (3) company's financial statement analysis and its comparison with other companies; (4) external variables such as securities return and bond valuation. In this study, financial distress was predicted using financial ratio analysis reflected in the company's financial statements. 
Three motives for conducting the study on financial distress prediction in the company were (1) to examine the influence of financial ratio variables on the financial distress measurement, (2) to re-examine the previous studies, and (3) to contribute to the company by providing an overview of financial conditions based on the results of this study. The result of this study also can be a reference for the company to improve its future performance. This study aimed to describe the influence of financial ratio on financial distress either simultaneously or partially.

\section{Methods}

\subsection{Population and data}

This study used quantitative descriptive methods. It describes the current research object based on facts, and then it is analyzed and interpreted [7]. This study used a quantitative approach because it assessed and analyzed data in numbers using SPSS with multiple linear regression analysis. Before performing multiple linear regression analysis, classical assumption test was carried out.

The population of this study was the financial statemements in year 2014 to 2018 . The data used in this study were secondary and primary data obtained directly from the company. The secondary data were from the company's financial statements in year 2014 to 2018, while the primary data were from unstructured interviews with the operational director.

\subsection{Operationalization of vVariables}

The independent variables were the current ratio, debt to asset ratio, return on assets, profit margin on sales, and sales growth ratio. The current ratio is a ratio used to measure the company's ability to meet its short-term obligations that are due soon by using its total current assets [8].

$$
\text { Current ratio }=\frac{\text { Current Asset }}{\text { Current Liability }}
$$

Debt to asset ratio is a ratio that shows how much the company's assets are financed by debt. [8]

$$
\text { DAR }=\frac{\text { Total Debt }}{\text { Total Asset }}
$$

Return on assets is a ratio that shows how much the contribution of assets in creating net income. [8]

$$
\text { Return on Asset }=\frac{\text { Earning After Tax (EAT) }}{\text { Total Assets }}
$$

Profit margin on sales is a financial ratio used to measure the profit margin on sales.

$$
\text { Profit Margin on Sales }=\frac{\text { Earning After Interest and Tax }}{\text { Sales }}
$$


Sales growth ratio is an increase in the number of sales from year to year or from time to time (Kesuma, 2009: 41) in [9]:

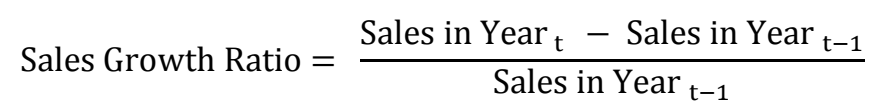

Meanwhile, the dependent variable was financial distress-the company's financial condition in an unhealthy or crisis state. Financial distress is defined as the stage of decline in financial conditions before bankruptcy [10].

$$
\text { Interest Coverage Ratio }=\frac{\mathrm{EBT}}{\text { Interest Expense }}
$$

\subsection{Hypothesis}

In recent years, companies engaged in printed mass media, such as PT XYZ, have experienced a decline in sales, resulting in financial difficulties. Based on this situation, prediction of financial distress is important to conduct so that companies pay more attention and anticipate things that can lead to the possibility of financial difficulties and bankruptcy. One way to predict financial distress is by analyzing financial ratios.

The lower the value of the current ratio, the lower the company's ability to meet its shortterm obligations, so that the company will likely experience greater financial distress. The greater the total debt to asset ratio, the greater the risk of the company experiencing difficulties in paying off its short-term and long-term obligations, so that the company is in financial distress. The lower the value of return on assets, indicating that the assets used for the company's operations are not able to provide benefits for the company, so that if the profitability of a company continues to decline, the possibility of the company experiencing financial distress is greater. The lower the value of the profit margin on sales, the lower the company's ability to generate profits, so that the company can experience losses and be in financial distress. The lower the sales growth ratio, it is feared that the company will experience financial difficulties in the future.

The following framework describes the relationship between the current ratio, total debt to asset ratio, return on assets, profit margin on sales, and sales growth ratio to financial distress predictions (Fig.3). 


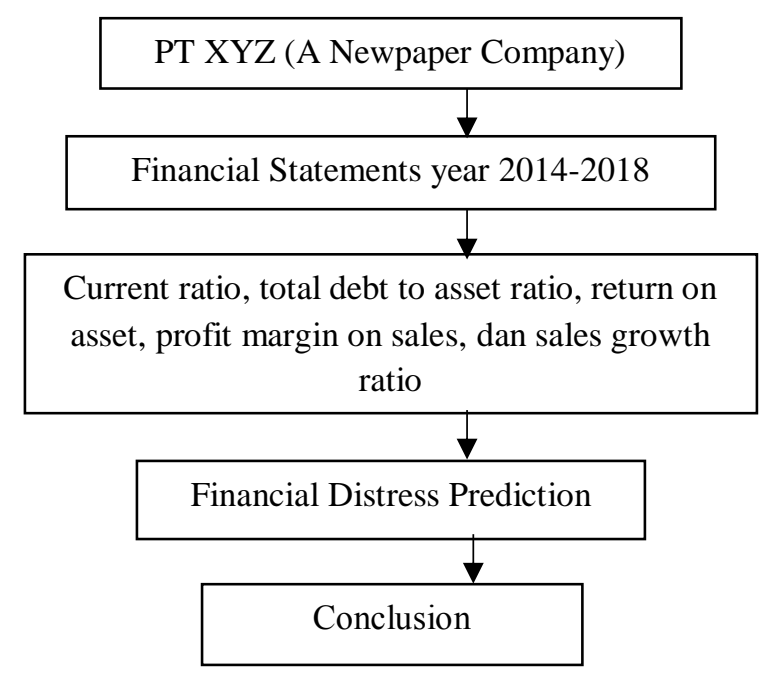

Fig. 3. Research Framework

Based on the research framework in figure 3, the hypotheses of this study are formulated as follows.

$\mathrm{H}_{1}$ : Current ratio has a partial influence on financial distress at PT XYZ in 2014-2018.

$\mathrm{H}_{2}$ : Total debt to asset ratio has a partial influence on financial distress at PT XYZ in 20142018.

$\mathrm{H}_{3}$ : Return on assets has a partial influence on financial distress at PT XYZ in 2014-2018.

$\mathrm{H}_{4}$ : Profit margin on sales has a partial influence on financial distress at PT XYZ in 20142018.

$\mathrm{H}_{5}$ : Sales growth ratio has a partial influence on financial distress at PT XYZ in 2014-2018.

$\mathrm{H}_{6}$ : Current ratio, total debt to asset ratio, return on assets, profit margin on sales, and sales growth ratio have a simultaneous influence on financial distress at PT XYZ in 20142018.

\section{Result}

\subsection{Descriptive statistics}

Descriptive statistical analysis is necessary to analyze data by describing the collected data. It aims to provide an overview or description of the variables in the study. The descriptive statistical analysis consists of determining the minimum value, maximum value, average value (mean), and standard deviation (std.deviation).

The following table shows the condition of the current ratio, total debt to asset ratio, return on assets, profit margin on sales, and sales growth ratio to financial distress at PT. XYZ in 2014-2018 using SPSS 23(Table 1). 
Table 1. Descriptive Statistical Analysis

\begin{tabular}{lcrrrr}
\hline \multicolumn{5}{c}{ Descriptive Statistics } \\
\hline & $\mathrm{N}$ & Minimum & Maximum & \multicolumn{1}{c}{ Mean } & Std. Deviation \\
\hline $\begin{array}{l}\text { Current Ratio } \\
(\mathrm{X} 1)\end{array}$ & 20 & .497 & .950 & .75711 & .162995 \\
$\begin{array}{l}\text { Total Debt to } \\
\text { Asset Ratio } \\
(\mathrm{X} 2)\end{array}$ & 20 & 1.251 & 2.289 & 1.57305 & .342082 \\
$\begin{array}{l}\text { Return On } \\
\text { Asset (X3) }\end{array}$ & 20 & -.163 & .131 & .04263 & .109542 \\
$\begin{array}{l}\text { Profit Margin } \\
\text { On Sales (X4) }\end{array}$ & 20 & -.061 & .068 & .02469 & .048401 \\
$\begin{array}{l}\text { Sales Growth } \\
\text { Ratio (X5) }\end{array}$ & 20 & -.164 & .284 & .10597 & .133469 \\
$\begin{array}{l}\text { Financial } \\
\text { Distress (Y) }\end{array}$ & 20 & .568 & 3.722 & 1.98515 & 1.089666 \\
$\begin{array}{l}\text { Valid N } \\
\text { (listwise) }\end{array}$ & 20 & & & & \\
\hline
\end{tabular}

Table 1 presents the statistical results of the independent and dependent variables.

1. Current Ratio

Based on the data, the current ratio has the lowest (minimum) value by 0.497 and the highest (maximum) value by 0.950 . Meanwhile, the calculation of the mean or average value of the current ratio is 0.75711, and the standard deviation (Std. Deviation) is 0.162995 . The standard deviation value that is lower than the mean value indicates that the current ratio has a low level of data variation.

2. Total Debt to Asset Ratio

The total debt to asset ratio has the lowest (minimum) value by 1.251 and the highest (maximum) value by 2.289. Meanwhile, the calculation of the mean or average value of the total debt to asset ratio is 1.57305 , and the standard deviation (Std. Deviation) is 0.342082 . The standard deviation value that is lower than the mean value indicates that the total debt to asset ratio has a low level of data variation.

3. Return on Asset

The Return on asset ratio has the lowest (minimum) value by -0.163 and the highest (maximum) value by 0.131 . Meanwhile, the calculation of the mean or average value of the return on assets is 0.04263 , and the standard deviation (Std. Deviation) is 0.109542 . The standard deviation value that is higher than the mean value indicates that the return on assets has a high level of data variation.

4. Profit Margin on Sales

Profit margin on sales ratio has the lowest (minimum) value by -0.061 and the highest (maximum) value by 0.068 . Meanwhile, the calculation of mean or average value of the profit margin on sales is 0.02469 , and the standard deviation (Std. Deviation) is 0.048401 . The standard deviation value that is higher than the mean value indicates that the profit margin on sales has a high level of data variation.

5. Sales Growth Ratio 
Sales growth ratio has the lowest (minimum) value by -0.164 and the highest (maximum) value by 0.284 . Meanwhile, the calculation of the mean or average value of the sales growth ratio is 0.10597, and the standard deviation (Std. Deviation) is 0.133469. The standard deviation value that is higher than the mean value indicates that the sales growth ratio has a high level of data variation.

6. Financial Distress

Financial distress ratio has the lowest (minimum) value by 0.568 and the highest (maximum) value by 3.722. Meanwhile, the calculation of the mean or average value of financial distress is 1.98515, and the standard deviation (Std. Deviation) is 1.089666. The standard deviation value that is lower than the mean value indicates that financial distress has a low level of data variation.

\subsection{Classical assumption test}

Before performing multiple linear regression analysis and hypothesis tests, the researchers performed classical assumption test. The test aims to provide certainty that the regression equation obtained has accuracy in estimating. Some of the classic assumption tests in this study includes multicollinearity test, normality test, heteroscedasticity test, and autocorrelation test.

\subsubsection{Multicolinierity Test}

According to (Ghozali, 2016), the multicollinearity test was used to test whether a correlation between the independent variables is found in the regression model. A good regression model shows no correlation between the independent variables. The measurement criteria are as follows:

1. If the VIF value is $\leq 10$, there will be no multicollinearity.

2. If the VIF value> 10, multicollinearity occurs.

Meanwhile, [11] quotes a statement from (Weiss, 2010) regarding multicollinearity which states:

"Multicollinearity does not adversely affect the ability of the sample regression equation to predict the response variable. Multicollinearity does not significantly affect point estimates of the target variable, confidence intervals for the mean response value, or prediction intervals for a randomly selected response value".

Selain itu, [12] mengungkapkan bahwa:

"Multicollinearity is not a problem when suppose X2 and X3 highly collinear, but $t$ statistic p-values on both $<5 \%$. So, neither appears insignificant".

Based on the above statement, it concludes that a good regression model is a model that does not experience multicollinearity. However, the occurrence of multicollinearity is not a problem if the significance value is $<0.05$ and the coefficient value is in accordance with the theory. The following are the results of the multicollinearity test on the current ratio variable, total debt to asset ratio, return on assets, profit margin on sales, and sales growth ratio, to financial distress using SPSS 23 (Table 2). 
Table 2. Multicolinierity Test

\begin{tabular}{|c|c|c|c|c|c|c|}
\hline \multicolumn{7}{|c|}{ Coefficients $^{\mathrm{a}}$} \\
\hline \multirow[t]{2}{*}{ Model } & \multicolumn{2}{|c|}{$\begin{array}{l}\text { Unstandardized } \\
\text { Coefficients }\end{array}$} & \multirow{2}{*}{$\begin{array}{c}\text { Standardized } \\
\text { Coefficients } \\
\text { Beta }\end{array}$} & $\mathrm{t}$ & \multicolumn{2}{|c|}{$\begin{array}{l}\text { Collinearity } \\
\text { Statistics }\end{array}$} \\
\hline & B & Std. Error & & Sig. & Tolerance & VIF \\
\hline 1 (Constant) & 10.672 & 2.664 & & 4.007 .001 & & \\
\hline Current Ratio (X1) & -7.945 & 1.713 & -1.188 & $4.639^{-.000}$ & .041 & 24.161 \\
\hline $\begin{array}{l}\text { Total Debt to Asset } \\
\text { Ratio (X2) }\end{array}$ & -2.183 & .873 & -.685 & $2.500^{-.025}$ & .036 & 27.683 \\
\hline Return On Asset (X3) & -24.969 & 4.720 & -2.510 & $5.290^{-.000}$ & .012 & 82.892 \\
\hline $\begin{array}{l}\text { Profit Margin On Sales } \\
\text { (X4) }\end{array}$ & 77.548 & 10.485 & 3.445 & 7.396 .000 & .013 & 79.859 \\
\hline $\begin{array}{l}\text { Sales Growth Ratio } \\
\text { (X5) }\end{array}$ & -.828 & .548 & -.101 & $1.510^{-.153}$ & .602 & 1.662 \\
\hline
\end{tabular}

a. Dependent Variable: Financial Distress (Y)

Source : SPSS Output Results

Table 2 shows that the variables of current ratio (X1), total debt to asset ratio (X2), return on assets (X3), profit margin on sales (X4) are experiencing multicollinearity problems because the VIF value $>10.00$ and the Tolerance value $<0.10$. Meanwhile, the sales growth ratio (X5) variable does not experience multicollinearity problems.

In accordance with the theory proposed by (Greene, 2002), the multicollinearity problem with the current ratio variable (X1), total debt to asset ratio (X2), return on assets $(\mathrm{X} 3)$, profit margin on sales (X4) is not a problem because the result of the significance value of each variable $<0.05$ and the value and direction of the coefficient are in accordance with the theory. Therefore, multiple linear regression analysis can be performed.

\subsubsection{Normality test}

According to (Ghozali, 2016), the normality test is used to find out whether the independent and dependent variables are normally distributed. Good regression models either have a normal or near normal distribution. The normality test can be conducted using the Kolmogornov-Smirnov (K-S) method. If the value is sig. $>0.05$ then the distribution of the regression model is normal. The following are the results of the normality test using the Kolmogrov Smirnov method with SPSS 23 (Table 3). 
Table 3. Normality Test

\begin{tabular}{llr}
\hline \multicolumn{2}{c}{ One-Sample Kolmogorov-Smirnov Test } \\
\hline $\mathrm{N}$ & \multicolumn{1}{c}{$\begin{array}{c}\text { Unstandardized } \\
\text { Residual }\end{array}$} \\
Normal Parameters ${ }^{\mathrm{a}, \mathrm{b}}$ & Mean & 20 \\
& Std. Deviation & .0000000 \\
Most Extreme Differences & Absolute & .21248080 \\
& Positive & .083 \\
& Negative & .077 \\
Kolmogorov-Smirnov Z & & -.083 \\
Asymp. Sig. (2-tailed) & & .370 \\
a. Test distribution is Normal. & .999 \\
b. Calculated from data. & \\
\hline Source: Result output SPSS
\end{tabular}

Source: Result output SPSS

The table 3 shows that the score of the Asymp. Sig (2-tailed) is 0.999>0.05. Therefore, it concludes that the data are normally distributed. Thus, the assumptions or normality requirements in the regression model have been fulfilled.

\subsubsection{Heteroscedasticity Test}

According to Ghozali, 2016, the heteroscedasticity test is used to test whether in the regression model there is an inequality of variants from the residual value of one observation to another. A good regression model shows no heteroscedasticity.

Heteroscedasticity test can be conducted by referring to the scatterplot image on SPSS (Fig.4). If there is no clear pattern (wavy, widened then narrowed) in the scatterplot image, and the dots spread above and below the 0 on the $\mathrm{Y}$ axis, it means that the regression model does not experience heteroscedasticity. The following are the results of the heteroscedasticity test using SPSS 23. 
Scatterplot

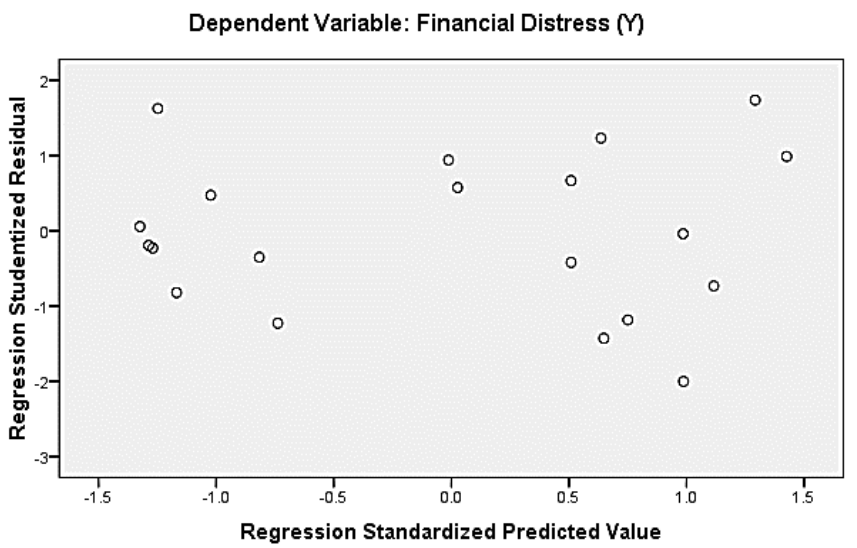

Figure 4. Heteroscedasticity test.

Source : SPSS Output Results

Figure 4 shows that there is no clear pattern in the scatterplot image and the dots spread above and below the number 0 on the $\mathrm{Y}$ axis. Therefore, the regression model does not experience heteroscedasticity symptoms.

\subsubsection{Autocorrelation Test}

According to Ghozali, (2016) [13], the autocorrelation test aims to test the linear regression model related to whether or not there is a correlation between the $\mathrm{t}$-period residual error and the error in the t-1 period (previously). A good regression model is a model that is free from autocorrelation. The autocorrelation test can be done by doing the Durbin-Watson $(\mathrm{D}-\mathrm{W})$ test or the runs test. This research uses a run test. In the runs test, there is no autocorrelation symptom if the Asymp value. Sig. (2-tailed)> 0.05 . The following are the results of the autocorrelation test using SPSS 23:

Table 4. Autokorrelation Test

\begin{tabular}{lr}
\hline \multicolumn{2}{c}{ Runs Test } \\
\hline \multicolumn{2}{c}{$\begin{array}{c}\text { Unstandardized } \\
\text { Residual }\end{array}$} \\
Test Value $^{\mathrm{a}}$ & -.02378 \\
Cases < Test Value & 10 \\
Cases >= Test Value & 10 \\
Total Cases & 20 \\
Number of Runs & 13 \\
Z & .689 \\
Asymp. Sig. (2-tailed) & .491 \\
a. Median & \\
\hline Source : SPSS output results
\end{tabular}


Based on table 4, the Asymp value is obtained. Sig. (2-tailed) of 0.491>0.05, which means that the regression model in this study did not experience autocorrelation symptoms.

\subsection{Multiple Linear Regression Test Results}

Multiple linear regression analysis is a tool to predict future demand based on past data [7]. Multiple linear analysis is to determine the influence and the relationship direction of one or more independent variables on one dependent variable. The following table presents the results of multiple linear regression analysis using SPSS 23 (Table 5).

Table 5. Multiple Linear Regression Test Results

\begin{tabular}{|c|c|c|c|c|c|}
\hline \multicolumn{6}{|c|}{ Coefficients $^{a}$} \\
\hline \multirow{2}{*}{ Model } & \multicolumn{2}{|c|}{$\begin{array}{c}\text { Unstandardized } \\
\text { Coefficients }\end{array}$} & $\begin{array}{l}\text { Standardized } \\
\text { Coefficients }\end{array}$ & \multirow{2}{*}{$\mathrm{T}$} & \multirow{2}{*}{ Sig. } \\
\hline & B & $\begin{array}{l}\text { Std. } \\
\text { Error }\end{array}$ & Beta & & \\
\hline 1 (Constant) & 10.672 & 2.664 & & 4.007 & 7.001 \\
\hline $\begin{array}{l}\text { Current Ratio } \\
\text { (X1) }\end{array}$ & -7.945 & 1.713 & -1.188 & 4.639 & -.000 \\
\hline $\begin{array}{l}\text { Total Debt to } \\
\text { Asset Ratio } \\
\text { (X2) }\end{array}$ & -2.183 & .873 & -.685 & $2.500^{-}$ & -.025 \\
\hline $\begin{array}{l}\text { Return On } \\
\text { Asset (X3) }\end{array}$ & -24.969 & 4.720 & -2.510 & $5.290^{-}$ & -.000 \\
\hline $\begin{array}{l}\text { Profit Margin } \\
\text { On Sales } \\
\text { (X4) }\end{array}$ & 77.548 & 10.485 & 3.445 & 7.396 & 6.000 \\
\hline $\begin{array}{l}\text { Sales Growth } \\
\text { Ratio (X5) }\end{array}$ & -.828 & .548 & -.101 & $1.510^{-}$ & -.153 \\
\hline
\end{tabular}

a. Dependent Variable: Financial Distress (Y)

From table 5 , the constant value is 10.672 , the current ratio coefficient is -7.945 , the total debt to asset ratio coefficient is -2.183 , the return on assets coefficient is -24.969 , the profit margin on sales coefficient is 77.548 , and the sales growth ratio coefficient is -0.828 . Then the regression equation can be formulated as follows.

$$
Y=10,672-7,945 X_{1}-2,183 X_{2}-24,969 X_{3}+77,548 X_{4}-0,828 X_{5}
$$

The equation above is interpreted as follows.

1. The constant value of the equation above is 10.672 , which means that financial distress is 10.672 units if the current ratio, total debt to asset ratio, return on assets, profit margin on sales, and sales growth ratio variables do not exist.

2. The current ratio variable has a negative regression coefficient value by -7.945 . It indicates that if there is an increase in the current ratio by $1 \%$, it will cause a decrease in the financial distress value by $7.945 \%$, assuming the other independent variables are considered constant. 
3. The total debt to asset ratio variable has a negative regression coefficient value by-2,183. It indicates that if there is an increase in the total debt to asset ratio by $1 \%$, it will cause a decrease in the financial distress value by $-2.183 \%$, assuming the other independent variables are considered constant.

4. The return on assets variable has a negative regression coefficient value by -24.969 . It indicates that if there is an increase in return on assets by $1 \%$, it will cause a decrease in the financial distress value by $-24.969 \%$, assuming the other independent variables are considered constant.

5. The variable profit margin on sales has a positive regression coefficient value of 77.548. It indicates that if there is an increase in profit margin on sales by $1 \%$, it will cause an increase in the financial distress value by $77.548 \%$, assuming the other independent variables are considered constant.

6 . The sales growth ratio variable has a negative regression coefficient value of -0.828 . The negative coefficient value indicates that if there is an increase in the sales growth ratio of 1 $\%$, it will cause a decrease in the value of financial distress by $0.828 \%$, assuming the other independent variables are considered constant.

\subsection{Hypothesis testing}

\subsubsection{The t-test}

According to [14], the t-test shows how far the independent variables partially influence the dependent variable so that it can conclude whether $\mathrm{H}_{0}$ is rejected or $\mathrm{Ha}$ is accepted from the formulated hypothesis.

If the significance value $<0.05$ and $\mathrm{t}$ count $>\mathrm{t}$ table, the independent variable influences the dependent variable. If the significance value $>0.05$ and $t$ count $<\mathrm{t}$ table, the independent variable does not influence the dependent variable. However, the value of $t$ table in this study with a significant rate of 0.05 and degrees of freedom $(\mathrm{df})=\mathrm{n}-\mathrm{k}=20-5=15$ was 2.131 .

Based on table 2, the hypothesis proposed in this study can be interpreted as follows.

1. The significance value for the influence of the current ratio variable $\left(\mathrm{X}_{1}\right)$ on financial distress $(\mathrm{Y})$ is $0.000<0.05$, and the $\mathrm{t}$ count value is $4.639>\mathrm{t}$ table 2.131 . It concludes that $\mathrm{H}_{0}$ is rejected, and $\mathrm{H}_{1}$ is accepted, which means that the current ratio influences financial distress.

2. The significance value for the influence of the variable of total debt to asset ratio $\left(\mathrm{X}_{2}\right)$ on financial distress $(\mathrm{Y})$ is $0.025<0.05$, and the $\mathrm{t}$ count value is $2.500>\mathrm{t}$ table 2.131 . It concludes that $\mathrm{H}_{0}$ is rejected, and $\mathrm{H}_{2}$ is accepted, which means total debt to assets ratio influences financial distress.

3. The significance value for the influence of the return on assets $\left(\mathrm{X}_{3}\right)$ variable on financial distress $(\mathrm{Y})$ is $0.000<0.05$, and the $\mathrm{t}$ count value is $5.290>\mathrm{t}$ table 2.131 . It concludes that $\mathrm{H}_{0}$ is rejected, and $\mathrm{H}_{3}$ is accepted, which means that return on assets influences financial distress.

4. The significance value for the influence of the variable profit margin is 7.396> $t$ table 2.131. It concludes that $\mathrm{H}_{0}$ is rejected, and $\mathrm{H}_{4}$ is accepted, which means that the profit margin on sales influences financial distress.

5. The significance value for the influence of the sales growth ratio $\left(\mathrm{X}_{5}\right)$ variable on financial distress $(\mathrm{Y})$ is $0.153>0.05$, and the $\mathrm{t}$ count value is $1.510<\mathrm{t}$ table 2.131 . It 
concludes that $\mathrm{H}_{0}$ is accepted, and $\mathrm{H}_{5}$ is rejected, which means that the sales growth ratio does not influence financial distress.

\subsubsection{F Test}

The $\mathrm{F}$ test is necessary to see whether the independent variables influence the dependent variable. In this study, the $\mathrm{F}$ test was to determine the influence of the current ratio, total debt to asset ratio, return on assets, profit margin on sales, and sales growth ratio on financial distress simultaneously. The following table presents the results of the F test using SPSS 23 (Table 6).

Table 6. F Test

\begin{tabular}{|c|c|c|c|c|c|c|}
\hline \multicolumn{7}{|c|}{ ANOVA $^{\mathrm{b}}$} \\
\hline \multicolumn{2}{|c|}{ Model } & $\begin{array}{l}\text { Sum of } \\
\text { Squares }\end{array}$ & Df & $\begin{array}{l}\text { Mean } \\
\text { Square }\end{array}$ & $\mathrm{F}$ & Sig. \\
\hline \multirow[t]{3}{*}{1} & $\begin{array}{l}\text { Regress } \\
\text { ion }\end{array}$ & 21.702 & 5 & 4.340 & $\begin{array}{r}70.83 \\
9\end{array}$ & $.000^{\mathrm{a}}$ \\
\hline & $\begin{array}{l}\text { Residua } \\
1\end{array}$ & .858 & 14 & .061 & & \\
\hline & Total & 22.560 & 19 & & & \\
\hline \multicolumn{7}{|c|}{$\begin{array}{l}\text { a. Predictors: (Constant), Sales Growth Ratio (X5), } \\
\text { Profit Margin On Sales (X4), Current Ratio (X1), Total } \\
\text { Debt to Asset Ratio (X2), Return On Asset (X3) }\end{array}$} \\
\hline \multicolumn{7}{|c|}{ b. Dependent Variable: Financial Distress (Y) } \\
\hline
\end{tabular}

If the significance value is $<0.05$ and $\mathrm{F}$ count is $>\mathrm{F}$ table, then there is an influence of the independent variable simultaneously on the dependent variable. Meanwhile, if the significance value is $>0.05$ and $\mathrm{F}$ count is $<\mathrm{F}$ table, then there is no influence of the independent variable simultaneously on the dependent variable. The value of the $\mathrm{F}$ table in this study with a significance rate by 0.05 and degrees of freedom $(\mathrm{df})=\mathrm{n}-\mathrm{k}=20-5=15$ is 2.90 .

Based on table 3, the F count value is 70.839, with a significance value of 0.000 . Because the significance value is $0.000<0.05$ and the value of $\mathrm{F}$ count is $70.839>\mathrm{F}$ table 2.90 . It concludes that $\mathrm{H} \_0$ is rejected, and $\mathrm{H} \_6$ is accepted, which means that the current ratio, total debt to asset ratio, return on assets, profit margin on sales, sales growth ratio have a simultaneous influence on financial distress.

\subsection{3 $R^{2}$ Test (Determination Coefficient Test)}

The determination coefficient test is carried out to measure how far the independent variable influences the dependent variable. The coefficient of determination explains the variation in the influence of the independent variables on the dependent variable.

The value used in this study was Adjusted R Square value because this study used more than one independent variables. This value can increase or decrease if an independent variable is added to the model. The following table shows the results of the determination coefficient test using SPSS 23 (Table 7). 
Table 7. Determination Coefficient Test

\begin{tabular}{|c|c|c|c|c|}
\hline \multicolumn{5}{|c|}{ Model Summary ${ }^{\mathrm{b}}$} \\
\hline $\begin{array}{l}\text { Mod } \\
\text { el }\end{array}$ & $\mathrm{R}$ & $\begin{array}{c}\mathrm{R} \\
\text { Square }\end{array}$ & $\begin{array}{l}\text { Adjusted } \\
\text { R Square }\end{array}$ & $\begin{array}{l}\text { Std. Error of the } \\
\text { Estimate }\end{array}$ \\
\hline 1 & $.981^{\mathrm{a}}$ & 962 & .948 & .247532645569 \\
\hline \multicolumn{5}{|c|}{$\begin{array}{l}\text { a. Predictors: (Constant), Sales Growth Ratio (X5), } \\
\text { Profit Margin On Sales (X4), Current Ratio (X1), Total } \\
\text { Debt to Asset Ratio (X2), Return On Asset (X3) }\end{array}$} \\
\hline \multicolumn{5}{|c|}{ b. Dependent Variable: Financial Distress (Y) } \\
\hline
\end{tabular}

Based on table 7 , the Adjusted $\mathrm{R}^{2}$ value is 0.948 or $(94.8 \%)$. It indicates that the variable of current ratio, total debt to asset ratio, return on assets, profit margin on sales, and sales growth ratio influence $94.8 \%$ of financial distress. Meanwhile, other variables that were not used in this study influence $5.2 \%$ of financial distress.

\section{Discussion}

\subsection{Influence of current ratio on financial distress}

The first hypothesis $\left(\mathrm{H}_{1}\right)$ of this study states that the current ratio influences financial distress. Based on the results of multiple linear regression analysis data, the current ratio has a negative and significant influence on financial distress. This condition is proven with the significance value by 0.000 , which is less than the required level of significance by 0.05 $(0.000<0.05)$. Meanwhile, the regression coefficient value has a negative direction by $-7,945$, which means that there is a negative relationship between the current ratio variable and financial distress.

A company is considered to have an excellent financial condition if it can guarantee its short-term liabilities with its current assets. This condition is reflected in the value of the current ratio that the higher the value of the current ratio, the lower the possibility of the company experiencing financial distress, and the company can maintain its survival. On the other hand, if the company does not have sufficient current assets and is unable to pay off its short-term liabilities at maturity, the possibility of the company experiencing financial distress will be even higher. From this condition, the first hypothesis $\left(\mathrm{H}_{1}\right)$ is accepted, and the current ratio negatively and significantly influences financial distress. This condition is supported with data evidence that the average value of PT XYZ's current ratio is $0.757<1$, which indicates that the total current assets are not able to fulfill their current liabilities properly. Therefore, the value of a low current ratio can increase financial distress in the company.

The result of this study is in line with research conducted by [15], which stated that the current ratio has a negative and significant influence on the prediction of financial distress in the company. The condition of the company that has a low liquidity value can increase the chances of financial distress. This research result is supported by research conducted by [10] which stated that the higher the current ratio value, the greater the protection for creditors so that the company's chance to experience financial distress is getting smaller.

On the other hand, [16] stated that the liquidity ratio does not influence financial distress conditions. The analysis result showed that the level of liquidity of a company cannot 
guarantee that the company will experience financial distress because the current ratio is a measure of short-term liquidity, while financial distress is a prediction for the long term.

\subsection{The influence of total debt to asset ratio on financial distress}

The second hypothesis $\left(\mathrm{H}_{2}\right)$ proposed in this study stated that the total debt to asset ratio influences financial distress. The results of multiple linear analyses shows that the total debt to asset ratio has a negative and significant influence on financial distress. This condition is proven with the $\mathrm{r}$ significance value by 0.025 , which is less than the required level of significance by $0.05(0.025<0.05)$. Meanwhile, the regression coefficient value has a negative direction by -2.183 , which means that there is a negative relationship between the total debt to asset ratio variable and financial distress.

In this study, the total average debt to asset ratio value as a whole is $1.573>1$, which means that the company has a high debt ratio value. It increases the risk of the company being unable to pay its debts at a later date. If the company is unable to pay off its debts, the possibility of the company experiencing financial distress is even getting higher.

Besides, the average value of the total debt to asset ratio decreased in 2014-2018 by 2.132 to 1.263 . The decrease in the debt value indicates that the creditor's level of confidence in PT $\mathrm{XYZ}$ to provide loans decreases. This decrease causes the company is difficult to get a loan for its survival so that the company can experience financial distress. This statement concludes that the total debt to asset ratio value $>1$, and it decreases every year, which lead to the increase of financial distress. In other words, the total debt to asset ratio has a negative influence on financial distress.

Research conducted by [17] stated that the total debt to asset ratio (DAR) has a significant influence in predicting financial distress. This research is supported by research conducted by [18], which stated that the higher the total debt to asset ratio value, the smaller the possibilities of the company experiencing financial distress.

On the other hand, research conducted by [16] stated that the leverage ratio has a positive influence on financial distress. The results of this analysis is in line with research conducted by [10], which stated the same thing. Meanwhile, according to [15], the total debt to asset ratio does not influence financial distress.

\subsection{Influence of return on assets on financial distress}

The third hypothesis $\left(\mathrm{H}_{3}\right)$ proposed in this study stated that return on assets influences financial distress. Based on the result of multiple linear regression analysis data, return on assets has a negative and significant influence on financial distress. This condition is proven with the significance value by 0.000 , which is less than the required level of significance by $0.05(0.000<0.05)$. Meanwhile, the regression coefficient value has a negative direction of 24.969, which means that there is a negative relationship between the current ratio variable and financial distress.

Return on assets is necessary to measure how much net profit is generated from each fund embedded in total assets. The lower the return on assets, the lower the amount of net income generated. If the company experiences a decrease in the value of return on assets every year, then the possibility of the company experiencing financial distress will be even greater. This condition is supported with data evidence that the average value of the ratio of return on assets at PT. XYZ in 2016-2018 decreases by 0.130 to 0.003 . 
The result of this study is in line with research conducted by [16], which stated that return on assets has a negative influence on financial distress. This research is supported by research conducted by [10] and [19] which stated the same thing. Meanwhile, [4] stated that return on assets does not influence financial distress.

\subsection{Influence of profit margin on sales on financial distress}

The fourth hypothesis $\left(\mathrm{H}_{4}\right)$ proposed in this study stated that profit margin on sales influences financial distress. Based on the results of multiple linear regression analysis data, the profit margin on sales has a positive and significant influence on financial distress. This condition is proven with the significance value by 0.000 , which is less than the required level of significance by $0.05(0.000<0.05)$. Meanwhile, the regression coefficient value has a positive direction by 77.548 , which means that there is a positive relationship between the variable profit margin on sales and financial distress.

The more value of profit margin on sales will lead to the chance of the company to experience financial distress. This condition will happen if the considerable sales value at PT $\mathrm{XYZ}$ is in the form of accounts receivable, which increases the risk of bad debts. Based on the evidence of PT XYZ's financial statements in 2014-2018, the company has an increased value of receivables and sales every year. The more receivable that cannot be collected, the higher the possibility of the company experiencing financial distress.

This research is in line with research conducted by [20] which stated that profit margin on sales has a positive influence on financial distress. This research is also supported by research conducted by [21], which stated the same thing. Meanwhile, according to [19], profit margin on sales does not influence financial distress predictions.

\subsection{The Influence of Sales Growth Ratio on Financial Distress}

The fifth hypothesis $\left(\mathrm{H}_{5}\right)$ proposed in this study stated that the sales growth ratio influenced financial distress. Based on the results of multiple linear regression analysis data, the regression coefficient value has a negative direction by -0.828 . While the significance value by 0.153 is more significant than the required level of significance, which is 0.05 $(0.153>0.05)$. It indicates that $\mathrm{H}_{5}$ is rejected, which means that the sales growth ratio does not influence financial distress.

The result of this study is in line with research conducted by [16], which stated that sales growth ratio does not influence financial distress. A company with a high sales growth rate does not guarantee that the company has high profits, so that it can avoid financial distress. It happens due to other factors, such as expenses that can affect company profits. Based on PT XYZ's financial statements in 2014-2018, the sales value that increases every year is not in line with the net profit generated. Therefore, in this study, the value of the sales growth ratio does not influence financial distress.

Meanwhile, according to [15], the sales growth ratio has a negative and significant influence on financial distress. The lower the sales growth ratio value of a company, the higher the possibility of the company experiencing financial distress. 


\subsection{The Influence of Current Ratio, Total Debt to Asset Ratio, Return On Asset, Profit Margin on Sales, and Sales Growth Ratio to Financial Distress}

The sixth hypothesis $\left(\mathrm{H}_{6}\right)$ proposed in this study stated that the current ratio, total debt to asset ratio, return on assets, profit margin on sales, and sales growth ratio have a simultaneous influence on financial distress. Based on the results of the F test, the significance value is $0.000<0.05$, and the F count value is $70.839>\mathrm{F}$ table 2.90 , which means that $\mathrm{H} 0$ is rejected, and $\mathrm{H} 7$ is accepted. Therefore, the result of this study supports the sixth hypothesis $\left(\mathrm{H}_{6}\right)$, where the current ratio, total debt to asset ratio, return on assets, profit margin on sales, and sales growth ratio simultaneously influence financial distress.

On the other hand, seeing from the results of the coefficient of determination $\left(\mathrm{R}^{2}\right.$ test), the Adjusted $\mathrm{R}^{2}$ value is 0.948 or $(94.8 \%)$, which showes that the variable of current ratio influences $94.8 \%$ of financial distress, total debt to asset ratio, return on assets, profit margin on sales, and sales growth ratio. Meanwhile, $5.2 \%$ is influenced by other variables that are not used in this study.

The result of this study is in line with research conducted by [22], which showed that leverage, profitability, and company size simultaneously influence financial distress. This result is also supported by research conducted by [23], which stated that simultaneously liquidity, leverage, sales growth, and company size have a significant influence on financial distress.

\subsection{Advice for the Company:}

In overcoming financial difficulties experienced by PT XYZ, several suggestions to avoid bankruptcy are proposed after observing the data and research results. They are mentioned as follows.

1. The company must be able to reduce the number of bad debts by implementing a strict policy against newspaper selling agents in order to pay off their debts.

2. The company management may consider the decision to sell some of the company's assets or keep them.

3. The company can apply for credit restructuring to the bank.

4. The Shareholders can prioritize the principle of togetherness to improve the company's financial condition by deferring their rights and prioritizing the employee salary to reduce company expenses.

5. The company must maintain credibility for the news published. That way, the company's credibility will remain well-known in the community because it provides reliable news and is free from conflicts of interest.

6. The company can continue to improve its innovation and marketing, such as increasing its presence on social media or radio so that it is not only famous in their print media but also other media.

\section{Conclusion}

Based on the analysis, this study revealed the following results.

1. Current ratio partially has a negative influence on financial distress at PT XYZ in 20142018. 
2. Total debt to asset ratio partially has a negative influence on financial distress at PT XYZ in 2014-2018.

3. Return on assets partially has a negative influence on financial distress at PT XYZ in 20142018.

4. Profit margin on sales partially has a positive influence on financial distress at PT XYZ in 2014-2018.

5. Sales growth ratio partially does not influence financial distress at PT XYZ 2014-2018.

6. The current ratio, total debt to asset ratio, return on assets, profit margin on sales, and sales growth ratio simultaneously have a significant influence on financial distress at PT XYZ in 2014-2018.

\section{References}

[1] Kusuma, S.: Posisi Media Cetak Di Tengah Perkembangan Media Online Di Indonesia Satria Kusuma, J. InterAct, vol 5, no 1, bll 56-71, (2016).

[2] Bryllian, J.: Keberadaan Koran Meredup Dengan Munculnya New Media, no September, (2015).

[3] Brahmana, R. K.: Identifying Financial Distress Condition In Indonesia Manufacture Industry, J. Bus., bll 1-19, (2007).

[4] Khadapi, M.: Pengaruh Car, Roa, Bopo Dan Fdr Terhadap Financial Distress Bank Umum Syariah Di Indonesia Periode 2014-2016, Unpubl. Thesis - UIN Syarif Hidayatullah, (2017).

[5] Platt, H. D. en Platt, M. B.: Predicting Corporate Financial Distress: Reflections On Choice-Based Sample Bias, J. Econ. Financ., vol 26, no 2, bll 184-199, (2002), doi: 10.1007/BF02755985.

[6] Widarjo, W. en Setiawan, D.: Pengaruh Rasio Keuangan Terhadap Kondisi Financial Distress Perusahaan Otomotif, J. Bisnis dan Akunt., vol 11, no 2, bll 107-119, (2009).

[7] Siregar, S.:Metode Penelitian Kuantitatif. Jakarta: Prenadamedia Group, (2013).

[8] Hery:Analisis Laporan Keuangan Pendekatan Rasio Keuangan. Jakarta: CAPS (Center for Academic Publishing Service), (2015).

[9] Yudiaatmaja, F.: Profitabilitas Terhadap Struktur Keuangan, vol 4, no 1, (2016).

[10] Yeni, Y.: Pengaruh Likuiditas, Leverage, Profitabilitas,Operating Capacity Dan Biaya Agensi Manajerial Terhadap Financial Distress (Studi Empiris Pada Perusahaan Manufaktur Yang Terdaftar Di Bursa Efek Indonesia Tahun 2011-2013, Jom FEKON, vol 2, no 2, (2015).

[11] Larose, C. D. en Larose, D. T.:Data science using Python and R. John Wiley \& Sons, (2019).

[12] Greene, W. H.:Econometric Analysis 4th Ed. (2002).

[13] Ghozali:Aplikasi Analisis Multivariete dengan Program IBM SPSS. Diponegoro: Badan Penerbit Universitas Diponegoro, (2016).

[14] Sugiyono:Metode Penelitian Kuantitatif Kualitatif dan R\&D. Bandung: Alfabeta, (2013).

[15] Widhiari, N. en Aryani Merkusiwati, N.: Pengaruh Rasio Likuiditas, Leverage, Operating Capacity, Dan Sales Growth Terhadap Financial Distress, E-Jurnal Akunt., vol 11, no 2, bll 456-469, (2015).

[16] Agustini, N. W. en Wirawati, N. G. P.: Pengaruh Rasio Keuangan Pada Financial Distress Perusahaan Ritel Yang Terdaftar Di Bursa Efek Indonesia (BEI), E-Jurnal Akunt., vol 26, bl 251, (2019), doi: 10.24843/eja.2019.v26.i01.p10.

[17] Marota, R.Alipudin, A.en Maiyarash, A.: Pengaruh Debt To Assets Ratio (Dar), 
Current Ratio (Cr) Dan Corporate Governance Dalam Memprediksi Financial Distress Pada Perusahaan Bumn Sektor Non Keuangan Yang Terdaftar Di Bursa Efek Indonesia, J. Ilm. Akunt. Fak. Ekon., vol 4, no 2, bll 249-266, (2018), doi: 10.1056/nejmoa1407279.

[18] Yudiawati, R. en Indriani, A.: Analisis Pengaruh Current Ratio, Debt To Total Asset Ratio, Total Asset Turnover, Dan Sales Growth Ratio Terhadap Kondisi Financial Distress Pada Perusahaan Manufaktur, Diponegoro J. Manag., vol 5, no 2, bll 1-13, (2016).

[19] Hapsari, E. I.: Kekuatan Rasio Keuangan Dalam Memprediksi Kondisi Financial Distress Perusahaan Manufaktur Di Bei, JDM (Jurnal Din. Manajemen), vol 3, no 2, bll 101-109, (2013), doi: 10.15294/jdm.v3i2.2438.

[20] Yuanita, I.: Prediksi Financial Distress Dalam Industri Textile Dan Garment (Bukti Empiris Di Bursa Efek Indonesia), J. Akunt. dan Manaj., vol 5, no 1, bll 101-119, (2010).

[21] Sulastri, E. en Zannati, R.: Prediksi Financial Distress Dalam Mengukur Kinerja Perusahaan Manufaktur, J. Manaj. Strateg. dan Apl. Bisnis, vol 1, no 1, bll 27-36, (2018), doi: 10.36407/jmsab.v1i1.17.

[22] HendraAfrizalen Diah, E.: Faktor-Faktor Yang Mempengaruhi Financial Distress (Studi Empiris Pada Perusahaan Pertambangan Yang Terdaftar Di Bursa Efek Indonesia Periode 2014-2016), (2018).

[23] Sopian, D. en Rahayu, W. P.: Pengaruh Rasio Keuangan Dan Ukuran Perusahaan Terhadap Financial Distress (Studi Empiris Pada Perusahaan Food And Beverage Di Bursa Efek Indonesia), Compet. J. Akunt. dan Keuang., vol 1, no 2, (2017), doi: 10.31000/competitive.v1i2.240. 